\title{
LOCATION AND WELFARE IN CITIES: IMPACTS OF POLICY INTERVENTIONS ON THE URBAN POOR*
}

\author{
Mudit Kapoor, Somik V. Lall, Mattias K. A. Lundberg, Zmarak Shalizi \\ Development Research Group, World Bank \\ Washington DC 20433, USA
}

\begin{abstract}
Informal settlements are an integral part of the urban landscape in developing countries. These settlements are widely distributed within cities, including central business centers and peripheral areas with environment hazards. In most cases, residents of these settlements do not have access to basic public services and amenities. In this paper, we examine the impact of interventions, such as upgrading basic services and resettlement policies, on the welfare of residents of these informal settlements, who are typically the urban poor. To examine these interventions, we estimate models of residential location choice and allow households to be sensitive to commuting costs to work, demand for public services, and preferences for community composition. Our empirical analysis is based on recently collected survey data from Pune, India, and shows that poor households prefer to live close to work and in communities that consist of people sharing common socio-demographic characteristics. From the perspective of households living in informal settlements, upgrading settlements in situ is welfare enhancing. If a household must be relocated, it greatly prefers to be moved to a community that resembles its current community.
\end{abstract}

\section{World Bank Policy Research Working Paper 3318, May 2004}

The Policy Research Working Paper Series disseminates the findings of work in progress to encourage the exchange of ideas about development issues. An objective of the series is to get the findings out quickly, even if the presentations are less than fully polished. The papers carry the names of the authors and should be cited accordingly. The findings, interpretations, and conclusions expressed in this paper are entirely those of the authors. They do not necessarily represent the view of the World Bank, its Executive Directors, or the countries they represent. Policy Research Working Papers are available online at http://econ.worldbank.org.

\footnotetext{
* This paper is part of a larger effort to understand the impact of spatial policy interventions on welfare and livelihoods of the urban poor. The research and data collection have been co-funded by a World Bank research program grant on "Urbanization and Quality of Life" and the UK DFID's Urban Knowledge Generation and Toolkits program. The authors can be contacted at mkapoor@worldbank.org (Kapoor), slall1@worldbank.org (Lall), mlundberg@worldbank.org (Lundberg) and zshalizi@worldbank.org (Shalizi). We would like to thank Maureen Cropper, David LeBlanc, Christopher Timmins, and seminar participants at the World Bank for useful comments.
} 


\section{LOCATION AND WELFARE IN CITIES: IMPACTS OF POLICY INTERVENTIONS ON THE URBAN POOR}

\section{BACKGROUND AND MOTIVATION}

The economic geography of cities is inherently uneven. There is considerable variation in housing quality, public services, local amenities, and household characteristics among neighborhoods, as well as within neighborhoods. We observe segregation and ethnic clustering almost as commonly as seeing high-rise apartment developments located next to slum and squatter settlements. ${ }^{1}$ Aggregate phenomena of sorting and mixing are intrinsically driven by residential location choices at the household level. Our interest is in examining residential choices in developing country cities, as these cities face unprecedented population growth and limiting fiscal constraints. In particular, we want to examine location decisions of households living in informal (slum and squatter) settlements, as many new entrants are likely to locate in these under-serviced sites within the city.

In many developing country cities, heterogeneity in land management practices allows different patterns of development (on both public and private land) across parts of the urban landscape. This leads to under-developed or undeveloped land parcels in many parts of the city. These parcels of land often become home to numerous poor residents in the form of slum and squatter settlements, with limited public services. These settlements are often subject to natural hazards (such as flooding), as well as negative environmental (such as illnesses from nearby sewerage sites) and transport externalities (such as the consequences of being located next to railway tracks or roads with polluting and dangerous traffic). The World Bank (2001) estimates conservatively ${ }^{2}$ that more than 300 million urban poor in developing countries live in slum and squatter settlements, most of them being squalid, unsafe environments that create health and security

\footnotetext{
${ }^{1}$ We use the terms 'slum', 'squatters' and 'informal settlements' interchangeably in this paper

${ }^{2}$ Habitat estimates as many as 800 million, using different methodology.
} 
problems. ${ }^{3}$ Regionally, it is estimated that there are 200 million slum dwellers in Asia, more than 50 million in Latin America and the Caribbean, and more than 60 million in African cities.

Many land policy interventions have efficiency objectives, that is, to realize the value of land for the landowners, and lead to the eviction of slum-dwellers, with or without compensation. Some policy interventions are motivated by poverty-reduction objectives. Policy interventions to enhance the welfare of the poor or the slum dwellers include 'slum upgrading' programs, which typically improve availability and access to local public services and amenities in situ. These programs may also include investments to improve the quality and characteristics of dwelling units. In principle, upgrading not only increases the welfare of the slum dwellers who have received these interventions, but may also 'spill over' to increase welfare of non-slum dwellers in the neighborhood. These external benefits could include increases in overall property values through improvements in neighborhood attributes (such as better exteriors and less garbage on the streets) as well as direct improvements in levels of public services (particularly those provided on a network, such as water supply and sanitation). From a political economy perspective, the presence of benefit spillovers of slum upgrading programs to non-slum dwellers is important in ensuring the viability of upgrading initiatives. This is because any strategy on behalf of the poor / slum dwellers is unlikely to be approved in the political or 'voting' process if it has adverse consequences or no benefits for non-poor / non-slum dwellers, who presumably bear a disproportionately higher burden of taxes to finance local public goods.

This paper looks at the poverty-reduction objectives that improve the welfare of the slum-dweller, and not the efficiency objective of maximizing the value of the land. We examine the residential location decisions of slum dwellers and the impact of urban upgrading on their welfare. In particular, we ask the following questions: (a) Why are slum dwellers willing to under-consume housing services and live in hazardous and under-serviced (albeit usually central) locations? (b) How do slum dwellers value

\footnotetext{
${ }^{3}$ http://web.mit.edu/urbanupgrading/upgrading/
} 
location-based attributes and amenities? and (c) What is the impact of slum upgrading on the welfare of the beneficiaries? In future work, we will also take up the question of benefit spillovers to non-slum dwellers, and the relative gains to different groups from different interventions.

To answer these questions, we first need to examine how households make residential location choices within a city, thereby sorting themselves across neighborhoods. We must assess the relative premiums that households are willing to pay for intra-city differentials in location specific characteristics, such as access to employment opportunities, levels of public services and amenities, and sociodemographic composition of the neighborhood or community. Presumably, these location-based attributes translate into pecuniary and non-pecuniary benefits. For the empirical analysis, we employ a recently completed household survey from Pune, India to examine how households make residential location choices. The survey is georeferenced and can be linked to neighborhood attributes, so that it becomes possible to examine spatially differentiated location choices across neighborhoods.

We extend the analysis described above by considering a scenario in which growth, along with efforts to improve overall urban efficiency, creates pressure to reduce the volume of under-utilized land in central or high-value parts of the city. A common perception is that slum and squatter settlements in central areas do not use land efficiently and productively. ${ }^{4}$ Policies to increase land-use efficiency might involve the relocation or displacement of slum dwellers to peripheral or marginal lands. There are numerous instances where slum dwellers have been evicted from their current locations. For example, in 1999 a BBC report indicated that two million slum dwellers in Bangladesh were to be evicted and their homes demolished. Apparently, the government announced that all slums in the capital city Dhaka were to be razed, and no alternate accommodation would be provided to these slum dwellers. ${ }^{5}$ Similarly, in 2002, about 2,300 families

\footnotetext{
${ }^{4}$ While there is abundance of anecdotal evidence pointing to the contrary, there is very little rigorous evidence showing that this perception is incorrect

${ }^{5} \mathrm{http}: / /$ news.bbc.co.uk/1/hi/world/south_asia/338153.stm; there are other similar cases, for instances Manila under the Marcos regime (see Jimenez 1984).
} 
living in slums near the Buckingham Canal in Chennai, India were evicted, and there was no clear indication on the nature of compensation provided to the displaced slum dwellers. $^{6}$

The main normative goal of this analysis is to discover the mechanisms through which it is possible to protect or compensate for the loss of welfare among the poor, as policies and regulations are changed to improve aggregate efficiency in resource allocation. If enhancing efficiency were the main objective of reforms, the resulting outcome would be Pareto-superior if, in principle, there would be net gains overall, after compensating those who are displaced (even if no compensation is actually given). In practice, it is generally assumed that those relocated are worse off than they would have been had they remained in their original homes, that is, displacement of poor households reduces their welfare. This is a cause for concern if poverty reduction is a separate objective, independent of increasing aggregate efficiency in resource allocation. In addition, there is anecdotal evidence that the displaced simply return to their former places of residence, thus eliminating much of the supposed efficiency gains from resource reallocation.

In this context, we ask the following additional questions: (a) What would be the welfare impact of relocating slum dwellers from their current locations to less desirable peripheral locations; and (b) Can we design a package of interventions that leaves the relocated households as well off as they would be if they had been allowed to remain in their current homes?

We make several methodological innovations to answer the questions raised here. First, we explicitly include a household's preference for community structure in our estimation strategy, thereby allowing us to pick up premiums that households are willing to pay for non-pecuniary factors. These include social and kinship networks in the community or neighborhood measured by sharing common language and religion, as well as similarities in educational attainment. Second, we estimate a utility function where we

\footnotetext{
${ }^{6} \mathrm{http} / / /$ www.hinduonnet.com/thehindu/2002/08/09/stories/2002080907290300.htm
} 
assume that each household makes an optimal location choice given the set of alternatives and the location decisions of other households. The estimates from this approach provide us with a household's preferences for a set of neighborhood characteristics, which are allowed to vary across households.

Our general results from the empirical analysis show that households are willing to pay significant premiums to locate in areas that are composed of households sharing common socio-demographic characteristics. Sorting takes place on own language and religion, similar educational attainment, and average length of tenure in the neighborhood. Households are willing to pay significant premiums to maintain social and kinship networks. In addition, although transport costs matter, they are less important, for slum-dwellers, than community characteristics.

We then use the estimation results to conduct set of simulations, to examine potential impacts of alternative slum interventions. The interventions we examine are:

1. upgrading public services to households in situ;

2. relocating individual households from a central slum to a peripheral ward;

3. relocating individual households to a peripheral ward, and upgrading public services in the new location;

4. relocating communities to a peripheral ward; and

5. relocating communities to a peripheral ward, and upgrading public services.

We can rank potential interventions in terms of their impact on the welfare of slum dwellers in Pune. The simulations we conduct later in this paper reveal that relative to no intervention (allowing slum dwellers to remain in their current location, with the same service levels and housing conditions), upgrading services in situ is the only policy intervention examined that increases the welfare of the poor in the absence of any credible compensation mechanism.

In summary, in this paper, we provide a general analytic strategy to evaluate the impact of potential interventions on the welfare of poor slum dwellers. Following this 
introduction, the rest of the paper is organized in five sections. Section II provides the analytic and estimation strategy. In Section III, we provide some contextual information on Pune city, as well as describe some aspects of the data used for the empirical analysis. Results from the empirical analysis are provided in Section IV. Impacts of relocation vs. upgrading are evaluated in Section V. Section VI concludes and also presents additional questions that will be examined in future research.

\section{ANALYTIC StRATEGY}

In this section, we discuss various factors that influence residential location choices of households. Following this discussion, we present the estimation framework, and the simulation approach that is used to examine the impacts of slum upgrading and relocation interventions.

\section{Factors Influencing Residential Location Decisions}

There is considerable antecedent analytic work examining the factors that influence residential location choices in urban areas. There are three main factors that are generally modeled in this context: (a) commuting costs, (b) local public goods, and (c) individual preferences for community or neighborhood composition. ${ }^{7}$

The importance of commuting or transport costs is motivated by Alonso (1964) and Mills (1967) who demonstrate how residential choices are defined by the relationship between relative expenditures on commuting and land consumption. They modeled the metropolitan area as a "monocentric city" - that is, the metropolitan area has a central business district (CBD) at its center to which each household commutes. Taking a bidprice approach to household location decisions where commuting or travel costs are capitalized in the bid-price for land, locations closer to the CBD are more valuable than those at the periphery. In these bidding and sorting models, households maximize their

\footnotetext{
${ }^{7}$ These models are inspired by US and European (primarily British) experience. This paper provides an indirect test of the usefulness of these models for developing countries - although the evidence is suggestive rather than conclusive.
} 
bid-price offer for housing subject to the constraint that such payments leave the household no worse off than any other alternative. If the demand for land is income elastic, then richer households will be better off by purchasing land that is further from the $\mathrm{CBD}$ and are compensated for the increase in travel or commuting costs. In this case, we would see aggregate sorting of richer households toward the periphery and poorer households near the CBD. In contrast, if demand for land is income inelastic and commuting costs increase with income, then larger savings in commuting costs for the richer households will make them outbid poor households for the locations closer to the CBD. Thus, the location choices of households and the final sorting outcome would depend on the extent to which the income elasticity of land demand is greater or smaller than the income elasticity of the cost of commuting.

Our model accounts for the trade-off between the demand for land and commuting time, although we drop the restrictive assumption of the monocentric city. We have data on the ward in which each household head is primarily employed, and use that to construct a measure of the distance to work for each household. Our estimation strategy allows the household to choose its location partly on the basis of the distance to its current job from each alternative residential location within the city.

Tiebout's (1956) model of fiscal competition brings into play the role of local public services in the location decisions of households. In this model, communities or jurisdictions provide public services (which are financed by local taxes) to their residents. In making a residential location choice, a household will shop across communities and choose the one that provides the composition and level of public services that best satisfy the household's demand. If expenditures on public goods increase with income, then households with different incomes will tend to choose different communities, and households in the same community will tend to have similar incomes (McGuire 1974; Berglas 1976; Wooders 1978). In the aggregate, this may lead to sorting based on preferences and demand for locally financed public services. In Pune, as in many developing-country cities, neither revenues nor services are locally (i.e., at the neighborhood or ward level) controlled. However, we should still see sorting across level 
of services, since there is considerable intra-city variation in amenities and service delivery, even if the variation is not the result of competition among neighborhoods to attract tax-paying residents.

In addition to commuting costs and public service provision, individual preferences for community composition appear to be an important factor in the decision making process. This is most famously articulated in the works of Thomas Schelling $(1969,1971,1978)$ whose models of social interaction show that microeconomic forces such as discriminatory individual preferences or behavior lead to aggregate phenomena such as sorting and segregation. This model implies that people are willing to pay differential premiums to live near others who share common socio-economic or demographic characteristics. These characteristics include religion, class, language, educational attainment, and duration of stay and tenure in the city. In a recent paper, Lall et al. (2004) argue that social interaction and participation tend to increase with cultural, ethnic or economic homogeneity. In other words, individuals have an aversion to heterogeneity if it implies that they will be forced to associate with people who are not like themselves. A "cost" of participation in neighborhood activities, therefore, is the act of association itself; and this cost is higher in more diverse communities.

Jha et. al (2002) show that social networks in Delhi slums perform three main functions: survival, mobility, and providing access to public services. For example, they find that friends and neighbors in the slum provided shelter to families who had their homes demolished. Similarly, social networks provide avenues for slum dwellers to access credit in times of need, as well as routine informal services such as providing daycare to children and organizing "neighborhood watches" to keep an eye on property. We found similar anecdotal evidence of benefits from social and kinship networks during focus group community meetings that were held prior to implementing the household survey in Pune.

In reality, none of these analytic models can completely explain residential location choices by themselves. A combined approach - including commuting costs, 
public services, and individual preferences for community characteristics - is likely to be more useful to examine the strength of the various sorting mechanisms on residential location choice decisions by households. Furthermore, demand for various housing and neighborhood attributes varies with household characteristics. Thus, the empirical work should be sensitive to inter-household differences in various characteristics (such as family size, number of earners, number of children) and the resulting differences in premiums for various housing and neighborhood amenities.

We now describe the analytic strategy and parametric estimates used to specify and estimate the residential location choice model for Pune city.

\section{Estimation Strategy}

In this section we outline the estimation strategy for residential location choice. For estimation we use a random utility model in which utility to a household from alternative choices of wards (administrative unit) is specified as a linear function of characteristics of consumers, attributes of alternative choices of wards, and an error term. Specifically let $V_{w}^{i}$ be the utility from choosing ward $w$ to $i$ th household. We define

$$
V_{w}^{i}=\alpha_{X}^{i} X_{w}^{i}-\alpha_{D}^{i} D_{w}^{i}-\alpha_{p}^{i} p_{w}+d_{w}+\varepsilon_{w}^{i}
$$

where $X_{w}^{i}$ represents the observed characteristic of the neighborhood for $i$ th household in ward $w$. To construct the neighborhood characteristics for each household we take the values of each household's nearest 15 neighbors. We assume that the household chooses between its current dwelling unit and a random dwelling unit in each of the other 47 wards in the city. For each household, therefore, we define the characteristics of the other wards as simply the ward averages. These characteristics include the share of households in the neighborhood that are Hindu, scheduled caste, Marathi speakers, the proportion of female headed households, the average age of household heads in the ward, the average size of households in the ward, the number of children per household, the proportion who feel that the neighborhood is safe for women, the average number of 
years households have resided in their current house, the proportion of household heads born in the city, and the proportion of household heads with primary, secondary, or higher education. $D_{w}^{i}$ is the commuting time of $i$ th household from ward $w$ to the ward where the head of the household works. $d_{w}$ is the dummy variable that captures the unobserved (to the econometrician) characteristics of the ward which can affect the household's utility. These ward characteristics are observed by each household at the time they are making their decision but not captured in the data. Ignoring these effects will bias the estimates, since they could be related to other observed characteristics of the ward like prices and socio-demographic factors. $\varepsilon_{w}^{i}$ is the idiosyncratic error term. In our estimation we are assuming that each household takes the prices or ward premiums, as well as social and demographic characteristics associated with each ward as given and makes rational residential location choice decisions. For purpose of estimation this assumption translates into a condition where the idiosyncratic error term is independent of the ward characteristics.

The $\alpha_{j}^{i}$ 's for $j \in\{X, D, p\}$ in equation (1) are the parameters of the utility function with respect to each attributes of the choices. In our analysis, each household's valuation of the choice characteristic is allowed to vary with its own characteristics, for that reason we allow the parameters to have a superscript that indexes the household. Specifically,

$$
\alpha_{j}^{i}=\alpha_{0 j}+\sum_{r=1}^{R} \alpha_{r j} Z_{r}^{i}
$$

where $\alpha_{0 j}$ is the parameter on ward attributes that is common to all households and $\sum_{r=1}^{R} \alpha_{r j} Z_{r}^{i}$ is the parameter that depends on household characteristics $Z_{r}^{i}$. These household characteristics are the same as those describing the ward characteristics, plus the log value of the income (flow) from durable goods to the household. 
The $i$ th household will choose ward $w$ if $V_{w}^{i} \geq V_{k}^{i}$ for all $k$, where $k$ indexes all the possible ward choices to $i$ th household. For estimation we will assume that $\varepsilon_{w}^{i}$ is additively separable from the rest of the utility function, and has a Weibull distribution, which leads to a conditional logit specification,

$$
P_{w}^{i}=\frac{\exp \left(\alpha_{X}^{i} X_{w}^{i}-\alpha_{D}^{i} D_{w}^{i}-\alpha_{p}^{i} p_{w}+d_{w}\right)}{\sum_{k} \exp \left(\alpha_{X}^{i} X_{k}^{i}-\alpha_{D}^{i} D_{k}^{i}-\alpha_{p}^{i} p_{k}+d_{k}\right)}
$$

in which $P_{w}^{i}$ is the probability that $i$ th household chooses ward $w$.

\section{Parametric Estimates}

We use the estimates of our conditional logit model to derive the parameters of the utility function defined in (1). We can rewrite (1) by replacing the parameters with its estimated values. Specifically,

$$
\hat{V}_{w}^{i}=\hat{\alpha}_{X}^{i} X_{w}-\hat{\alpha}_{D}^{i} D_{w}^{i}-\hat{\alpha}_{p}^{i} p_{w}+\hat{d}_{w},
$$

where $\hat{\alpha}_{j}^{i}=\hat{\alpha}_{0 j}+\sum_{r=1}^{R} \hat{\alpha}_{r j} Z_{r}^{i}$, for $j \in\{X, D, p\}$. We will use equation (4) as the basis of our policy experiments.

\section{Simulations for examining the impact of policy interventions}

As mentioned earlier, we can use the empirical results to conduct a series of policy experiments, to examine the consequences of alternative interventions among slum-dwelling households. In the first experiment, we upgrade basic services in a representative slum, by reducing by half the number of households without sewerage. Since we upgrade them at their current location, the only changes come from variations in access to public services; we evaluate the change in welfare for the slum dweller due to the upgrading. Second, we displace the slum dweller from his current location to a peripheral location. This is done in a number of ways: we relocate the slum dweller along with his original community, and we relocate him by himself. In both cases, we also provide improved services in the new location. For these cases, we evaluate the 
change in welfare of the slum dweller due to relocation and due to the change in services. Through these simulations, we will be able to evaluate the impact of alternate spatial interventions on the welfare of the slum dwellers. The results from these simulations are presented and discussed in Section V.

\section{Case Study of Pune City}

In this section, we describe the dataset and variables that have been used in the empirical analysis. Pune has a population of 2.8 million, of whom close to one million live in slum settlements distributed throughout the city (Bapat and Agarwal 2003). The city is located in the state of Maharashtra, approximately 200 kilometers south east of Mumbai.

The empirical analysis draws on household survey data from Pune, India, which was collected between August and October 2002, and designed to be representative of the Pune Municipal Corporation area. All households of the city are part of the sampling universe with the exception of residents of military cantonments and institutional populations (for example, prisons). For our survey, 2,850 households were randomly selected and they responded to questions regarding socioeconomic characteristics, quality and quantity of housing, tenure status, and access to infrastructure services. The final survey instrument also used a travel diary to record daily activity patterns of household members. To ensure that all parts of the city are covered by the sample, we chose sample fractions in each of the 48 wards (administrative units) in proportion to the number of households of that ward according to the preliminary estimates of the Census of March 2001. Primarily because of problems with limited responses for the travel diary, our final sample consists of 1,322 households - fewer than half of those originally interviewed. ${ }^{8}$

\footnotetext{
${ }^{8}$ We re-estimated the regressions using the entire sample, attributing to each household the mean values of travel times for nearest neighbors and wards, in the manner described above for neighborhood characteristics. Those results (available on request) confirm the results presented here. We use the restricted sample simply to reduce measurement error.
} 
For the purpose of this analysis, we classified the households into four housing types. These classes are based on the type of settlement in which they live. Type 1 households live in informal settlements (slums), Type 2 live in the core city, Type 3 live in formal developments, and Type 4 live in urban villages. Informal settlements include households living in non-notified and notified slum and squatter settlements, slum resettlement communities, and unauthorized developments. Table 1 shows that 40 percent of sample households live in informal settlements. Dwelling units in this category are smaller than units in the other three categories. Figure 1 shows that sample households in informal settlements are not clustered or segregated in one part of the city, but in fact are spread all over the urban area. It is useful to note that many notified slums are located on or near riverbanks, which are susceptible to flooding during the monsoons.

The survey data show that in general, dwelling unit characteristics in the informal settlements are considerably worse than in other housing categories. For example, a majority of households living in informal settlements use community toilets. In contrast, a large proportion of households in formal developments use WC toilets that are connected to a functioning sewer system. The household survey also elicited the selfassessed exterior condition of the dwelling unit. We find that 27 percent of dwelling units in informal settlements have good exteriors compared to 65 percent for formal developments (see Table 2 for details).

As described in Section 2, the value of the dwelling unit is the household's willingness to pay (WTP) for a set of dwelling unit and neighborhood characteristics. To get an estimate of the household's WTP, we ask each household the following questions: "What would be the estimated present market price for a similar unit in this neighborhood?" and "What would be the estimated monthly rental value for a similar unit in this neighborhood?" A summary of both self-assessed purchase prices and monthly rents by housing category is also provided in Table 1. Residents of informal settlements (Type 1) estimate the total monthly rental value of their dwellings at less than one-third that of residents of formal developments (Type 3). On the other hand, the unit rental 
value (per square foot) of Type 1 dwellings (Rupees 3.34) is identical to that of Type 4 dwellings (Rupees 3.39).

For a casual indication of the extent to which households are satisfied with their current location attributes, we asked subjective questions on perceptions of satisfaction with various dwelling unit and location characteristics. Table 3 shows that most households are satisfied with their current residential locations. While satisfaction with location is lowest among households living in informal settlements, it is still quite high at 88 percent. When asked about basic infrastructure and services, a smaller share of households reports being satisfied. This is particularly the case for residents of informal settlements, of whom 30 percent expressed dissatisfaction with the level infrastructure and service provision. However, fewer than ten percent of respondents expressed any desire to make changes in their current home, or move to a new home. Among those households, residents of informal settlements and urban villages were much more interested in improvements to basic services ( 7 and 8 percent, respectively) than moving to a new home ( 2 and 1 percent, respectively). Conversely, residents of more formal settlements were relatively more interested in moving to a new home.

Since transport or commuting costs are an important part of the analytic models and empirical strategy, we provide some contextual information on mode used by household heads for commuting to work. These data are collected from travel diaries that were used to record activity patterns of household members. Walking and using twowheelers such as scooters and motorcycles are the dominant modes ( 25 percent each) followed by bus and bicycle (see Figure 2). Poor households tend to walk or ride a bicycle, having relatively shorter commuting times and distances compared to households using motorized transport. The empirical analysis in the next section provides the details on the impact of commuting costs and travel times on residential location choices.

As noted above, we conduct the policy simulations on four types of households, which differ in their household- and dwelling unit-characteristics. Table 4 describes the characteristics of the households used in the simulations and their neighborhoods. We 
have chosen four archetypal wards, to represent the characteristics and environments of our four housing types, selecting the wards in which each type of household predominates. For instance, Type 1 households are predominant in ward 38. As with most of the city's residents, Type 1 households in ward 38 are likely to be Marathispeaking and Hindu. About half are from scheduled castes. Type 1 households have as many members as the average households, but they have more children than average. These households are significantly poorer, and they are more likely to be uneducated, than residents of other types of settlements. The characteristics of the ward in which our archetypal Type 1 resident lives (ward 38) reflects the characteristics of the predominant group - that is, by definition, Type 1 residents. The characteristics of Type 2, 3, and 4 households are also presented in Table 4.

The final column of this table presents the characteristics of a typical ward on the periphery of the city. In the simulations below, we examine the impact of moving Type 1 households from the ward in which they predominate (38) to this outlying ward (5). In our simulations, a significant portion of the welfare impact of relocation is felt through differences in the characteristics of the destination ward. For instance, while nearly half of ward 38 residents are from scheduled castes, none of the residents in ward 5 are. This distinction begs the question of how much (if any) of a relocated household's reaction to the relocation is a due to any discrimination he experiences from residents of his new district, and how much is due to his own demand for homogeneity of community. ${ }^{9}$

\section{ESTIMATION RESULTS}

In this section we describe the results of the conditional logit (McFadden) regression of location choice as a function of the characteristics of the household and the neighborhood in which the dwelling is located. Tables 5 and 6 present the results of the conditional logit regression on location choice. The coefficients in Table 5 are difficult to interpret: they indicate a group's preference for characteristics of neighborhoods

\footnotetext{
${ }^{9} \mathrm{We}$ are examining the welfare impact of the intervention only from the perspective of the relocated household, and not from the perspective of the resident of the receiving ward. One measure of the relative
} 
relative to mean preferences, which are presented in Table 6 . We will not dwell on the significance and specific inference of these parameter estimates - we discuss them briefly here, but proceed quickly to the simulations.

A few of the coefficients on the diagonal of Table 5 are strongly significant, indicating sorting within these classes of households. For instance, scheduled caste households are more likely to choose wards in which there are more scheduled caste households; and households that have been longer resident prefer neighbors of similarly longer tenure. Wealthier households (those with greater income from assets) prefer to live among wealthier neighbors. One hypothesis that we maintained in the construction of the structural model was that female-headed households might exhibit significantly different preferences from the mean. This turns out not to be true - the interactions with a dummy for female-headed households are neither individually nor jointly significant. Table 6 presents the results for the community characteristics, without interactions. These are similarly hard to interpret, since the overall effect is the sum of these parameters and their interactions, at the means.

\section{ImPACT OF Alternate POLICY InTERVENTIONS}

In this section we present a simulation of two sets of plausible urban land policy interventions. The first involves upgrading the sewer system in a ward in which slumdwelling households predominate. The second is to relocate these slum dwelling households from their current location to a peripheral location (ward).

Using the parameter estimates derived above, we conduct five simulation exercises, which correspond to alternative combinations of these two policies. To recap, these are:

1. upgrading public services to slum households in situ;

importance of discrimination may be found in a comparison of the impacts on the welfare of the relocated 
2. relocating individual households from a central slum to a peripheral ward;

3. relocating individual households to a peripheral ward, and upgrading public services in the new location;

4. relocating communities to a peripheral ward; and

5. relocating communities to a peripheral ward, and upgrading public services.

We posit that the first option dominates the others, at least from the perspective of the household. Policy options 2 and 3 involve the removal of an individual household from its original dwelling, and from its community, to a peripheral ward. In options 4 and 5, we relocate households as communities to a peripheral ward. In these simulation, we move a household from his original location to a peripheral ward, and replicate in his new location the characteristics of the community from which he was removed. His new location is identical to his old location in every respect, except in the distance he must travel to work; we assume that the relocation does not require that he find new employment.

The results of these simulation exercises are summarized in Table 7 and Figure 3. We will discuss the results of each simulation in turn.

1) Upgrading slum dwellers in situ. In this exercise we upgrade the representative slum dweller by decreasing the share of slum households which is not connected to the sewer system. In ward 38 (where our archetypal slum-dweller lives), 27.1 percent of households are not connected to the sewer system. For the simulation, we cut this in half, to 13.6 percent. This improves the average condition of dwelling units in that ward, and has a positive impact on the welfare of slum dwellers.

2) Relocating slum dwellers individually (without upgrading). In this scenario, we simply move a slum household from his current dwelling to a peripheral ward. His neighborhood now has the characteristics of ward 5, rather than ward 38, whence he was removed. In this case, his welfare drops by more than 16 percent, relative to the base case (the status quo ante).

and the recipient households, but that is beyond the scope of this paper. 
3) Relocating the individual household, plus upgrading services. In this scenario, we move the individual household from ward 38 to ward 5, but we upgrade the local sewer system as in simulation (1); that is, we decrease the share of households without sewerage to 13.6 percent. The relocated household certainly considers this an improvement over the previous case - but still, his welfare declines 11 percent relative to the case in which he is allowed to remain in his current dwelling.

4) Relocating slum dwellers as a community, without upgrading services. In this case, as discussed above, we relocate the slum dweller from his original home to a new home in a community at the periphery, which is identical in almost every respect to his original community. We can think of this simulation as moving the slum dweller, together with the entire population of his neighborhood, to the new peripheral location. This policy maintains the community structure - the social networks or social capital - in which the slum-dweller had invested in his original community. Clearly, this dominates the previous two simulations in which the household is relocated by itself. However, even in this case, the household is burdened by the increase in the distance it must travel from its new location to its place of work (which we assume does not change). The increased commuting distance is equivalent to a 3.5 percent drop in welfare.

5) Relocating slum dwellers as a community, plus upgrading services. Here we move the community, as in simulation (4), plus we upgrade the sewer system as in simulations (1) and (3). As in simulation (4), the slum-dweller suffers from the increase in commuting costs, but he benefits from keeping his community intact. In addition, he benefits from the improvements to public services. Coincidentally, the welfare benefit from improved local sewer services (as before, so that 13.6 percent of households are without sewerage) is exactly enough to counteract the loss in welfare due to the travel time. In this case, the household is just as well off as he was in the absence of any intervention. 
These simulations permit us to order these interventions in terms of their impact on the welfare of residents living in Pune's informal settlements. In order of preference (but maintaining the original numbering), these are:

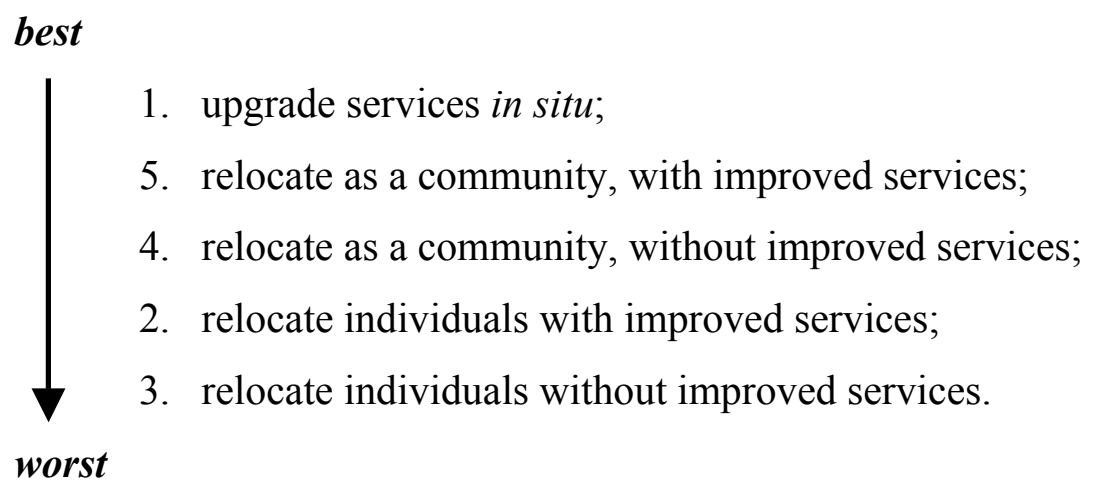

The simulations show that relative to no intervention (allowing slum dwellers to remain in their current location, with current levels of public services), upgrading services in situ is the only one of these interventions that increases welfare of the slum dwellers. In contrast, policies 4, 2, and 3 (from this list) reduce welfare, with the greatest loss coming from option 3 . If individual households are relocated from current locations to peripheral areas in the city, they would require additional compensation to leave them as well off as before the intervention. However, it must be mentioned that these results are sensitive to the characteristics of the ward to which these households are relocated. One general pattern which emerges from these results is that ward characteristics play an important role on household welfare and therefore should be accounted for in relocation and resettlement programs.

In option 5, in which the community is relocated and provided with better services, relocated households maintain the same community structure they had previously - there is minimal disruption to social networks. However, it is quite likely that access to other public services (water supply, solid waste collection, local schools and clinics, public transport) is considerably lower than at the previous more central location. Upgrading these other services to reduce the costs of displacement may even be welfare enhancing, relative to the status quo ante. In this case, no additional 
compensation is required, since the service improvements are sufficient to compensate for the loss incurred through the relocation.

These simulations suggest that individuals (both poor and non poor) place great value on the ability to live near others who share common socio-demographic characteristics. These characteristics include own religion and language (ethnicity), education attainment (human capital), and duration of tenure. ${ }^{10}$ In addition, households appear to have an aversion to wealth inequality, measured as the mean log deviation of income from assets. All these characteristics are indicators of the extent to which residents potentially interact with their peers, either for sharing information or providing a wide range of formal and informal services (including engaging in collective action; see Baland and Platteau, 1995). Displacing individual households (as in options 2 and 3), will have significant impacts on social and kinship networks. The loss of these networks imposes a significant cost, in terms of welfare, on relocated households. We find that in this case, improved services are not commensurate with this loss, and would necessitate much larger compensatory income transfers to leave the households as well off as before.

\section{CONCLUSIONS AND Future RESEARCH}

We have established that different policies for urban development have significantly different consequences for the welfare of slum dwellers. Clearly, improving dwelling unit quality on site dominates other options, such as relocation, even to improved dwelling units elsewhere. We have also shown that it is possible to find a package of interventions, in the form of service improvements, that compensates for the welfare loss incurred by the relocation. However, these results may be specific to Pune; it remains to be seen whether similar results will be obtained in other cities. Moreover, these results are also sensitive to the characteristics of the ward to which households are relocated.

\footnotetext{
${ }^{10}$ There are several reasons why duration of tenure and tenure security matter, such as greater incentive to invest in housing and community (Hoff and Sen 2002), and greater gains from social interaction (Hofferth and Iceland 1998, Bardhan 1993).
} 
Another contribution of our work is that the general methodology presented in this paper can be used in various settings to examine the potential impact of resettlement and relocation programs. Once we know the neighborhood characteristics, we are able to measure the welfare changes in relocated or resettled wards.

This research has focused on the welfare consequences of alternative policies on the welfare of slum dwellers. Although these results suggest significant welfare spillovers from policies that focus on slums to residents of other settlements, future work will confirm and measure these effects. ${ }^{11}$ The results yield the partial equilibrium impact of slum policies: we do include residential externalities of neighborhood composition, but we do not examine the city-wide general equilibrium effects of alternative uses of vacated slums in the case of relocation. While upgrading slums in "premium" locations is certainly welfare enhancing for the slum dwellers, the opportunity cost of land to the city for alternative uses may be relatively much higher at the same location. It may be that an alternative use of the land, such as the construction of a shopping center, is Pareto superior, even when the welfare costs of moving slum residents are considered. ${ }^{12}$

\footnotetext{
${ }^{11}$ Further work will also involve some methodological extensions. For example, we include ward-level dummies to capture both unobserved heterogeneity and within-ward correlations. However, it is possible that prices and other characteristics are likely to exhibit significant correlation over space, within and across wards. The price of houses in each ward will be related in some way to the price of houses in adjoining wards, controlling for house and ward-level attributes.

${ }^{12}$ Again, the Pareto criterion is usually applied in principle rather than in practice.
} 


\section{REFERENCES}

Alonso, W. 1964. Location and Land Use. Cambridge, Mass., Harvard University Press.

Baland, J.-M. and J.-P. Platteau. 1995. “ Does heterogeneity hinder collective action?” Facultes Universitaires Notre-Dame De La Paix, Namur.

Bapat, M. and I. Agarwal. 2003. Our needs, our priorities; women and men from the 'slums' in Mumbai and Pune talk about their needs for water and sanitation. Environment and Urbanization, 15, 2, 71-86.

Bardhan. P. 1993. Analytics of Informal Cooperation and Rural Development, World Development. 21, 4, 633-639

Berglas, E. 1976. On the theory of clubs, Papers and Proceedings of the American Economic Association, 66, 116-121.

Bayer, P., R. McMillan, and K. Reuben. 2002. "The Causes and Consequences of Residential Segregation: An Equilibrium Analysis of Neighborhood Sorting." In Submission, Econometrica.

Bayer, Patrick and C. Timmins. 2001. "Identifying Social Interactions in Endogenous Sorting Models.” mimeo, Yale University.

Hoff, K. and A. Sen. 2002. A Simple Theory of the Extended Family System and Market Barriers to the Poor. XXXX

Hofferth, S. and J. Iceland. 1998. Social Capital in Rural and Urban Communities. Rural Sociology, 63, 4: 574-598.

Jha, S., V. Rao, M. Woolcock. 2002. "Governance in the Gullies: Democratic responsiveness and community leadership in Delhi's slums." Paper presented at the Annual Bank Conference on Development Economics (ABCDE), World Bank.

Jiminez, E. 1984. "Tenure Security and Urban Squatting." Review of Economics and Statistics, $66,556-67$.

Lall, S.V., U. Deichmann, M. Lundberg, and N. Chaudhury. 2004. Tenure, Diversity and Commitment: Community Participation for Urban Service Provision. Journal of Development Studies, Forthcoming.

McFadden, D. 1978. "Modeling the Choice of Residential Location," in eds. Karlquist, A., et al., Spatial Interaction Theory and Planning Models, Elsevier North-Holland, New York.

McGuire, M. 1974. Group segregation and optimal jurisdictions. Journal of Political Economy, $82,112-132$.

Mills, E. 1967. An aggregative model of resource allocation in a metropolitan area. Papers and Proceedings of the American Economic Association, 57, 197-210. 
Ross, S.L., and J. Yinger. 1999. "Sorting and voting: a review of the literature on urban public finance" in The Handbook of Urban and Regional Economics, Vol 3, edited by P. Cheshire and E.S. Mills. Amsterdam: North Holland.

Schelling, T. C. 1969. Models of Segregation. American Economic Review, 59, 2: 488-93.

Schelling, T. C. 1971. Dynamic Models of Segregation. Journal of Mathematical Sociology, 1:143-186.

Schelling, T. C. 1978. Micromotives and Macrobehavior, Norton: New York.

Tiebout, C. 1956. A Pure Theory of Local Expenditures, Journal of Political Economy, 64: 416424.

Wooders, M. 1978. Equilibria, the core and jurisdictional structures in economies with a local public good. Journal of Economic Theory, 18, 328-348.

World Bank. 2001. Upgrading urban communities: A resource for practitioners. Available online at http://web.mit.edu/urbanupgrading/upgrading/. Accessed December 12, 2003. 
VIII. TABLES AND FIGURES

Table 1: Dwelling Unit Characteristics

\begin{tabular}{llrrrr}
\hline HCAT Description & Households Share & $\begin{array}{l}\text { Average } \\
\text { Living } \\
\text { Space } \\
\text { (Sq. ft) }\end{array}$ & $\begin{array}{l}\text { Average } \\
\text { Stated Price } \\
\text { (Rs.) }\end{array}$ & $\begin{array}{l}\text { Average Stated } \\
\text { Monthly Rent } \\
\text { (Rs.) }\end{array}$ \\
& & & & & \\
\hline 1 Informal Settlements & 1137 & $40 \%$ & 277 & 175,521 & 926 \\
2 Core City Housing & 643 & $23 \%$ & 341 & 599,181 & 2,305 \\
$\quad$ 3 Formal & 870 & $31 \%$ & 637 & 763,566 & 3,325 \\
$\quad \begin{array}{l}\text { Developments } \\
\text { 4 Urban Village }\end{array}$ & 199 & $7 \%$ & 542 & 425,447 & 1,836 \\
\hline Source: Pune Household Survey, 2001, The World Bank & & \\
\hline
\end{tabular}

Table 2: Quality of Dwelling Unit

\begin{tabular}{lcccc}
\hline Condition of Dwelling Unit & $\begin{array}{l}\text { Informal } \\
\text { Settlements }\end{array}$ & $\begin{array}{c}\text { Core City } \\
\text { Housing }\end{array}$ & $\begin{array}{l}\text { Formal } \\
\text { Developments }\end{array}$ & Urban Village \\
\hline Exterior & & & & \\
Good & $27 \%$ & $27 \%$ & $65 \%$ & $50 \%$ \\
Passable & $53 \%$ & $53 \%$ & $31 \%$ & $44 \%$ \\
Dilapidated & $20 \%$ & $21 \%$ & $4 \%$ & $6 \%$ \\
Interior & & & & \\
Good & $29 \%$ & $30 \%$ & $69 \%$ & $52 \%$ \\
Livable & $56 \%$ & $56 \%$ & $29 \%$ & $45 \%$ \\
Dilapidated & $15 \%$ & $14 \%$ & $2 \%$ & $4 \%$ \\
\hline Total & 1137 & 643 & 870 & 199 \\
\hline
\end{tabular}

Source: Pune Household Survey, 2001, The World Bank 
Table 3: Satisfaction with current location decisions

\begin{tabular}{|c|c|c|c|c|}
\hline Regional Characteristics & $\begin{array}{l}\text { Informal } \\
\text { Settlements }\end{array}$ & $\begin{array}{l}\text { Core City } \\
\text { Housing }\end{array}$ & $\begin{array}{l}\text { Formal } \\
\text { Developments }\end{array}$ & Urban Village \\
\hline \multicolumn{5}{|l|}{ Location } \\
\hline Dissatisfied & $10 \%$ & $4 \%$ & $3 \%$ & $5 \%$ \\
\hline Neutral & $2 \%$ & $1 \%$ & $0 \%$ & $3 \%$ \\
\hline Satisfied & $88 \%$ & $95 \%$ & $97 \%$ & $92 \%$ \\
\hline \multicolumn{5}{|c|}{ Infrastructure/ Basic Services } \\
\hline Dissatisfied & $30 \%$ & $15 \%$ & $12 \%$ & $43 \%$ \\
\hline Neutral & $6 \%$ & $6 \%$ & $1 \%$ & $4 \%$ \\
\hline Satisfied & $64 \%$ & $79 \%$ & $86 \%$ & $53 \%$ \\
\hline \multicolumn{5}{|l|}{ Would you ...... } \\
\hline Upgrade current home? & $7 \%$ & $1 \%$ & $1 \%$ & $8 \%$ \\
\hline Move to a new home? & $2 \%$ & $6 \%$ & $3 \%$ & $1 \%$ \\
\hline do nothing? & $91 \%$ & $93 \%$ & $96 \%$ & $91 \%$ \\
\hline Total & 1137 & 643 & 870 & 199 \\
\hline
\end{tabular}

Source: Pune Household Survey, 2001, The World Bank 
Table 4: Characteristics of households and communities used in simulations

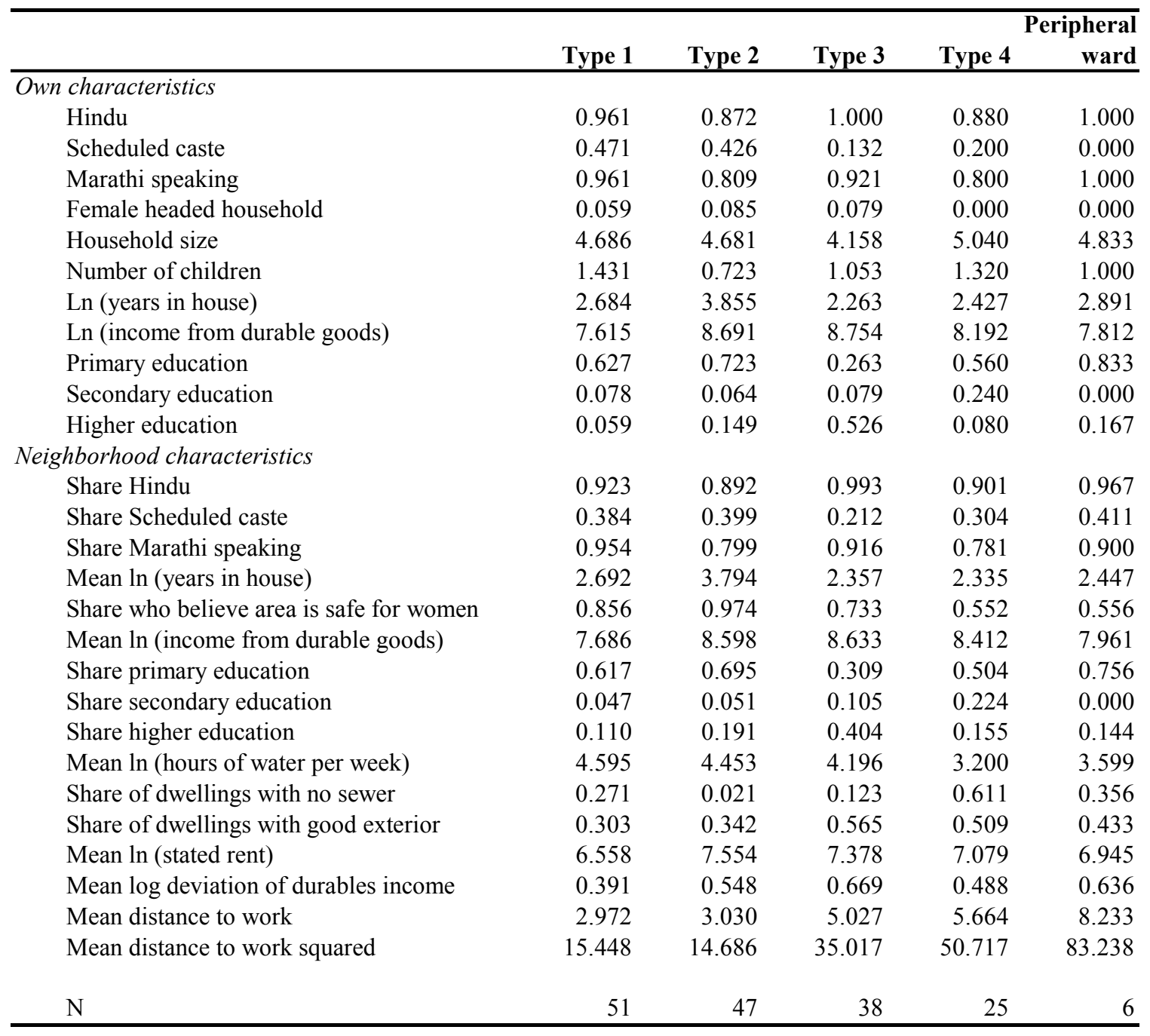




\section{Table 5: Parameter estimates on interactions in conditional logit}

\begin{tabular}{|c|c|c|c|c|c|c|c|c|c|c|c|}
\hline \multirow[b]{2}{*}{ Neighborhood characteristic } & \multicolumn{11}{|c|}{ Own characteristic } \\
\hline & Hindu & $\begin{array}{r}\text { Scheduled } \\
\text { caste }\end{array}$ & Marathi & $\begin{array}{r}\text { headed } \\
\text { household }\end{array}$ & $\begin{array}{r}\text { Household } \\
\text { size }\end{array}$ & Children & $\begin{array}{r}\text { Years in } \\
\text { house }\end{array}$ & $\begin{array}{r}\text { (durables } \\
\text { income) } \\
\end{array}$ & $\begin{array}{r}\text { Primary } \\
\text { education }\end{array}$ & $\begin{array}{r}\text { Secondary } \\
\text { education }\end{array}$ & $\begin{array}{r}\text { Higher } \\
\text { education }\end{array}$ \\
\hline \multirow[t]{2}{*}{ Share Hindu } & -1.555 & 2.213 & 1.333 & -2.927 & -2.053 & 2.079 & 1.036 & 2.241 & -6.743 & -11.951 & -1.840 \\
\hline & $(3.157)$ & $(1.858)$ & $(2.519)$ & $(3.284)$ & $(0.565) * *$ & $(0.836) *$ & $(0.862)$ & $(0.832) * *$ & $(2.639) *$ & $(3.666) * *$ & $(3.660)$ \\
\hline \multirow[t]{2}{*}{ Share Scheduled caste } & -2.144 & 3.934 & -0.510 & 0.108 & 0.251 & -0.572 & 1.151 & -0.185 & 3.828 & 3.561 & 4.391 \\
\hline & $(1.538)$ & $(0.885) * *$ & $(1.153)$ & $(1.611)$ & $(0.273)$ & $(0.396)$ & $(0.440) * *$ & $(0.378)$ & $(1.191) * *$ & $(1.735) *$ & $(1.774) *$ \\
\hline \multirow[t]{2}{*}{ Share Marathi speaking } & 2.892 & -1.333 & 2.477 & 1.770 & 0.629 & -0.396 & -1.958 & -1.339 & 2.346 & 4.709 & 0.238 \\
\hline & $(2.302)$ & $(1.412)$ & $(1.909)$ & $(2.483)$ & $(0.436)$ & $(0.640)$ & $(0.674) * *$ & $(0.647) *$ & $(1.909)$ & $(2.817)+$ & $(2.677)$ \\
\hline \multirow[t]{2}{*}{ Mean $\ln$ (years in house) } & -1.209 & 0.113 & -0.525 & -0.245 & 0.215 & -0.164 & 0.976 & -0.124 & 1.422 & 0.931 & 2.608 \\
\hline & $(0.609) *$ & $(0.339)$ & $(0.456)$ & $(0.602)$ & $(0.112)+$ & $(0.158)$ & $(0.160) * *$ & $(0.147)$ & $(0.486) * *$ & $(0.664)$ & $(0.663) * *$ \\
\hline \multirow[t]{2}{*}{ Share who believe area is safe for women } & -0.498 & 0.291 & -0.518 & 0.698 & -0.133 & -0.338 & 0.884 & 0.812 & 1.892 & 3.758 & 2.472 \\
\hline & $(1.382)$ & $(0.782)$ & $(1.035)$ & $(1.430)$ & $(0.251)$ & $(0.343)$ & $(0.349) *$ & $(0.331) *$ & $(1.057)+$ & $(1.473) *$ & $(1.474)+$ \\
\hline \multirow[t]{2}{*}{ Mean $\ln$ (income from durable goods) } & 0.060 & 1.002 & 0.901 & -0.737 & -0.122 & 0.301 & 0.305 & 0.761 & -1.418 & -4.613 & -1.806 \\
\hline & $(0.979)$ & $(0.548)+$ & $(0.745)$ & $(0.991)$ & $(0.176)$ & $(0.250)$ & $(0.255)$ & $(0.229) * *$ & $(0.772)+$ & $(1.119) * *$ & $(1.043)+$ \\
\hline \multirow[t]{2}{*}{ Share primary education } & -2.374 & 2.403 & -0.124 & 2.141 & -0.673 & -0.684 & 2.266 & 0.459 & 1.732 & 2.523 & -0.400 \\
\hline & $(2.553)$ & $(1.480)$ & (1.984) & $(2.736)$ & $(0.489)$ & $(0.692)$ & $(0.693) * *$ & $(0.698)$ & $(2.052)$ & $(2.955)$ & $(2.944)$ \\
\hline \multirow[t]{2}{*}{ Share secondary education } & -9.762 & 1.667 & -5.332 & 1.401 & 0.497 & -0.658 & -0.259 & -3.501 & 9.368 & 9.683 & 12.771 \\
\hline & $(3.766) * *$ & $(2.266)$ & $(2.937)+$ & $(4.200)$ & $(0.718)$ & $(1.031)$ & $(1.068)$ & $(1.048) * *$ & $(3.260) * *$ & $(4.518) *$ & $(4.517) * *$ \\
\hline \multirow[t]{2}{*}{ Share higher education } & -0.097 & 0.946 & -1.390 & 0.492 & -1.058 & -1.635 & 1.000 & -0.794 & 7.312 & 16.007 & 7.055 \\
\hline & (3.371) & (1.990) & $(2.566)$ & $(3.580)$ & $(0.651)$ & $(0.909)+$ & $(0.911)$ & $(0.898)$ & $(2.767) * *$ & $(3.923) * *$ & $(3.919)+$ \\
\hline \multirow[t]{2}{*}{ Mean $\ln$ (hours of water per week) } & -0.217 & 0.023 & -1.093 & 0.423 & 0.236 & 0.017 & 0.263 & -0.345 & -0.271 & -0.810 & 0.565 \\
\hline & $(0.567)$ & $(0.281)$ & $(0.416) * *$ & $(0.534)$ & $(0.096) *$ & $(0.132)$ & $(0.139)+$ & $(0.128) * *$ & $(0.381)$ & $(0.554)$ & $(0.554)$ \\
\hline \multirow[t]{2}{*}{ Share of dwellings with no sewer } & -0.307 & 0.832 & -2.703 & 0.391 & 0.100 & -0.153 & 0.436 & 0.092 & 2.374 & 3.299 & 4.363 \\
\hline & (1.218) & $(0.760)$ & $(0.956) * *$ & (1.447) & $(0.246)$ & $(0.346)$ & $(0.334)$ & $(0.332)$ & $(1.146) *$ & $(1.526) *$ & $(1.492) * *$ \\
\hline \multirow[t]{2}{*}{ Share of dwellings with good exterior } & -1.294 & -0.409 & 0.411 & -2.501 & 0.721 & -0.220 & 1.465 & -0.578 & 0.995 & -0.339 & 6.162 \\
\hline & (1.763) & (1.039) & $(1.381)$ & (1.788) & $(0.328) *$ & $(0.466)$ & $(0.486) * *$ & $(0.464)$ & (1.449) & (2.039) & $(2.041) * *$ \\
\hline \multirow[t]{2}{*}{ Mean $\ln$ (stated rent) } & 1.789 & -0.734 & -0.165 & 1.600 & -0.174 & -0.098 & 0.054 & 0.611 & 0.743 & 2.748 & 1.142 \\
\hline & $(0.935)+$ & $(0.528)$ & $(0.715)$ & $(0.987)$ & $(0.169)$ & $(0.241)$ & $(0.252)$ & $(0.232) * *$ & $(0.781)$ & $(1.086) *$ & (1.040) \\
\hline \multirow[t]{2}{*}{ Mean log deviation of durables income } & -0.067 & -1.274 & 1.537 & 1.066 & -0.349 & 0.509 & 0.213 & 0.448 & 0.713 & -0.436 & 2.021 \\
\hline & (1.077) & $(0.649) *$ & $(0.896)+$ & (1.154) & $(0.210)+$ & $(0.289)+$ & $(0.309)$ & $(0.286)$ & $(0.924)$ & $(1.303)$ & $(1.229)+$ \\
\hline \multirow[t]{2}{*}{ Mean distance to work } & -0.056 & -0.068 & 0.084 & -0.044 & 0.012 & -0.004 & -0.005 & 0.032 & 0.065 & -0.172 & 0.205 \\
\hline & $(0.156)$ & $(0.075)$ & $(0.102)$ & $(0.141)$ & $(0.025)$ & $(0.035)$ & $(0.035)$ & $(0.033)$ & $(0.103)$ & $(0.145)$ & $(0.148)$ \\
\hline \multirow[t]{2}{*}{ Mean distance to work squared } & 0.016 & 0.007 & -0.008 & 0.008 & 0.000 & -0.002 & 0.002 & -0.002 & -0.001 & 0.013 & -0.010 \\
\hline & $(0.017)$ & $(0.007)$ & $(0.009)$ & $(0.013)$ & $(0.002)$ & $(0.003)$ & $(0.003)$ & $(0.003)$ & $(0.009)$ & $(0.013)$ & $(0.013)$ \\
\hline $\mathrm{Chi}^{2}$ tests of joint significance (16 df) & $(30.24) *$ & $(40.33) * *$ & $(38.84) * *$ & $(10.93)$ & $(69.47) * *$ & $(27.56) *$ & $(150.50) * *$ & $(78.26) * *$ & $(43.76) * *$ & $(52.59) * *$ & $(55.61) * *$ \\
\hline
\end{tabular}

Note: ** significant at $<.01, *$ significant at $<.05,+$ significant at $<.10$. 
Table 6: Parameter estimates on other variables in conditional logit regression

\begin{tabular}{|c|c|}
\hline \multicolumn{2}{|l|}{ Neighborhood characteristics } \\
\hline Share Hindu & $\begin{array}{r}10.045 \\
(7.980)\end{array}$ \\
\hline Share Scheduled caste & $\begin{array}{r}-5.654 \\
(3.569)\end{array}$ \\
\hline Share Marathi speaking & $\begin{array}{r}3.805 \\
(6.123)\end{array}$ \\
\hline Mean $\ln$ (years in house) & $\begin{array}{c}-6.589 \\
(1.409) * *\end{array}$ \\
\hline Share who believe area is safe for women & $\begin{array}{r}-4.831 \\
(3.189)\end{array}$ \\
\hline Mean $\ln$ (income from durable goods) & $\begin{array}{l}-9.898 \\
(2.236) * *\end{array}$ \\
\hline Share primary education & $\begin{array}{l}10.301 \\
(6.311)\end{array}$ \\
\hline Share secondary education & $\begin{array}{l}60.133 \\
(9.468) * *\end{array}$ \\
\hline Share higher education & $\begin{array}{l}18.248 \\
(8.206) *\end{array}$ \\
\hline Mean $\ln$ (hours of water per week) & $\begin{array}{c}4.804 \\
(1.201)\end{array}$ \\
\hline Share of dwellings with no sewer & $\begin{array}{l}-15.653 \\
(3.176) * *\end{array}$ \\
\hline Share of dwellings with good exterior & $\begin{array}{r}-6.404 \\
(4.320)\end{array}$ \\
\hline Mean $\ln$ (stated rent) & $\begin{array}{l}-10.919 \\
(2.247) * *\end{array}$ \\
\hline Mean log deviation of durables income & $\begin{array}{l}-15.364 \\
(2.591) * *\end{array}$ \\
\hline Mean distance to work & $\begin{array}{l}-0.825 \\
(0.309) * *\end{array}$ \\
\hline Mean distance to work squared & $\begin{array}{r}0.012 \\
(0.028)\end{array}$ \\
\hline
\end{tabular}

\begin{tabular}{|c|c|c|c|c|c|}
\hline \multicolumn{6}{|c|}{ Ward dummy variables } \\
\hline Ward 2 & $\begin{array}{c}-4.443 \\
(0.630)\end{array} * *$ & Ward 18 & $\begin{array}{l}-12.557 \\
(0.725) * *\end{array}$ & Ward 34 & $\begin{array}{l}-14.765 \\
(0.826) * *\end{array}$ \\
\hline Ward 3 & $\begin{array}{l}-9.448 \\
(0.698) * *\end{array}$ & Ward 19 & $\begin{array}{l}-11.033 \\
(0.703) * *\end{array}$ & Ward 35 & $\begin{array}{l}-12.576 \\
(0.751) * *\end{array}$ \\
\hline Ward 4 & $\begin{array}{l}-11.927 \\
(0.700) * *\end{array}$ & Ward 20 & $\begin{array}{l}-12.462 \\
(0.641) * *\end{array}$ & Ward 36 & $\begin{array}{l}-11.198 \\
(0.729) * *\end{array}$ \\
\hline Ward 5 & $\begin{array}{c}-7.587 \\
(0.896)\end{array} * *$ & Ward 21 & $\begin{array}{l}-10.713 \\
(0.630) * *\end{array}$ & Ward 37 & $\begin{array}{l}-14.876 \\
(0.732) * *\end{array}$ \\
\hline Ward 6 & $\begin{array}{l}-5.842 \\
(0.538)\end{array} * *$ & Ward 22 & $\begin{array}{l}-13.646 \\
(0.705) * *\end{array}$ & Ward 38 & $\begin{array}{l}-14.835 \\
(0.734) * *\end{array}$ \\
\hline Ward 7 & $\begin{array}{c}-5.099 \\
(0.569)\end{array} * *$ & Ward 23 & $\begin{array}{l}-8.003 \\
(0.690) * *\end{array}$ & Ward 39 & $\begin{array}{l}-12.895 \\
(0.769) * *\end{array}$ \\
\hline Ward 8 & 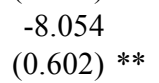 & Ward 24 & $\begin{array}{l}-5.697 \\
(0.619) * *\end{array}$ & Ward 40 & $\begin{array}{l}-13.247 \\
(0.734) * *\end{array}$ \\
\hline Ward 9 & $\begin{array}{c}-8.659 \\
(0.632)\end{array} * *$ & Ward 25 & $\begin{array}{c}-9.788 \\
(0.635) * *\end{array}$ & Ward 41 & $\begin{array}{l}-7.948 \\
(0.851) * *\end{array}$ \\
\hline Ward 10 & $\begin{array}{l}-7.539 \\
(0.644) * *\end{array}$ & Ward 26 & $\begin{array}{c}-4.948 \\
(1.042) * *\end{array}$ & Ward 42 & $\begin{array}{l}-13.236 \\
(0.834) * *\end{array}$ \\
\hline Ward 11 & $\begin{array}{c}-9.876 \\
(0.761)\end{array}$ ** & Ward 27 & $\begin{array}{l}-12.078 \\
(0.658) * *\end{array}$ & Ward 43 & $\begin{array}{l}-6.196 \\
(0.826) * *\end{array}$ \\
\hline Ward 12 & $\begin{array}{l}-1.910 \\
(0.624) * *\end{array}$ & Ward 28 & $\begin{array}{l}-8.346 \\
(0.790)\end{array}$ ** & Ward 44 & $\begin{array}{l}-12.447 \\
(0.840)\end{array} * *$ \\
\hline Ward 13 & $\begin{array}{l}-9.968 \\
(0.661) * *\end{array}$ & Ward 29 & $\begin{array}{l}-7.846 \\
(0.665) * *\end{array}$ & Ward 45 & $\begin{array}{l}-13.891 \\
(0.821) * *\end{array}$ \\
\hline Ward 14 & $\begin{array}{l}-8.534 \\
(0.623) * *\end{array}$ & Ward 30 & $\begin{array}{l}-9.971 \\
(0.695) * *\end{array}$ & Ward 46 & $\begin{array}{l}-10.277 \\
(0.742) * *\end{array}$ \\
\hline Ward 15 & $\begin{array}{l}-9.049 \\
(0.608) * *\end{array}$ & Ward 31 & $\begin{array}{l}-13.814 \\
(0.754) * *\end{array}$ & Ward 47 & $\begin{array}{l}-11.182 \\
(0.792) * *\end{array}$ \\
\hline Ward 16 & $\begin{array}{l}-7.748 \\
(0.634) * *\end{array}$ & Ward 32 & $\begin{array}{l}-14.040 \\
(0.792) * *\end{array}$ & Ward 48 & $\begin{array}{l}-8.969 \\
(0.786) * *\end{array}$ \\
\hline Ward 17 & $\begin{array}{l}-11.217 \\
(0.736) * *\end{array}$ & Ward 33 & $\begin{array}{l}-11.558 \\
(0.804) * *\end{array}$ & & \\
\hline
\end{tabular}

significant at $<.10$. 
Table 7: Simulation results - impact of alternative policy interventions

\begin{tabular}{lr}
\hline Intervention & $\begin{array}{r}\text { Change in } \\
\text { welfare } \\
\text { (percent) }\end{array}$ \\
\hline Upgrading in original location & 3.39 \\
Relocating individual & -16.66 \\
Relocating individual + upgrading & -11.14 \\
Relocating community & -3.41 \\
Relocating community + upgrading & -0.02 \\
\hline
\end{tabular}


Table X: Estimation results - total marginal effects of community characteristics

\begin{tabular}{lrrrr}
\hline & \multicolumn{4}{c}{ household type } \\
& Type 1 & Type 2 & Type 3 & Type 4 \\
\hline Share Hindu & 18.62 & 19.91 & 21.70 & 16.66 \\
Share Scheduled caste & -1.37 & 0.98 & -2.72 & -2.03 \\
Share Marathi speaking & -2.77 & -6.58 & -3.89 & -2.54 \\
Mean ln (years in house) & -4.65 & -2.99 & -4.62 & -4.60 \\
Share who believe area is safe for women & 3.45 & 6.08 & 4.59 & 4.22 \\
Mean ln (income from durable goods) & -3.43 & -2.91 & -3.46 & -4.21 \\
Share primary education & 15.87 & 19.77 & 14.37 & 15.10 \\
Share secondary education & 27.92 & 27.85 & 25.88 & 28.53 \\
Share higher education & 12.89 & 15.66 & 13.12 & 14.17 \\
Mean ln (hours of water per week) & 2.58 & 2.74 & 2.35 & 2.46 \\
Share of dwellings with no sewer & -14.00 & -12.30 & -13.08 & -13.33 \\
Share of dwellings with good exterior & -4.03 & -2.13 & -3.06 & -4.16 \\
Mean ln (stated rent) & -5.02 & -4.15 & -3.60 & -4.33 \\
Mean log deviation of durables income & -10.88 & -10.40 & -9.39 & -10.89 \\
Mean distance to work & -0.51 & -0.45 & -0.38 & -0.50 \\
Mean distance to work squared & 0.01 & 0.01 & 0.01 & 0.01 \\
\hline
\end{tabular}


Figure 1: Informal Settlements in the Pune Survey

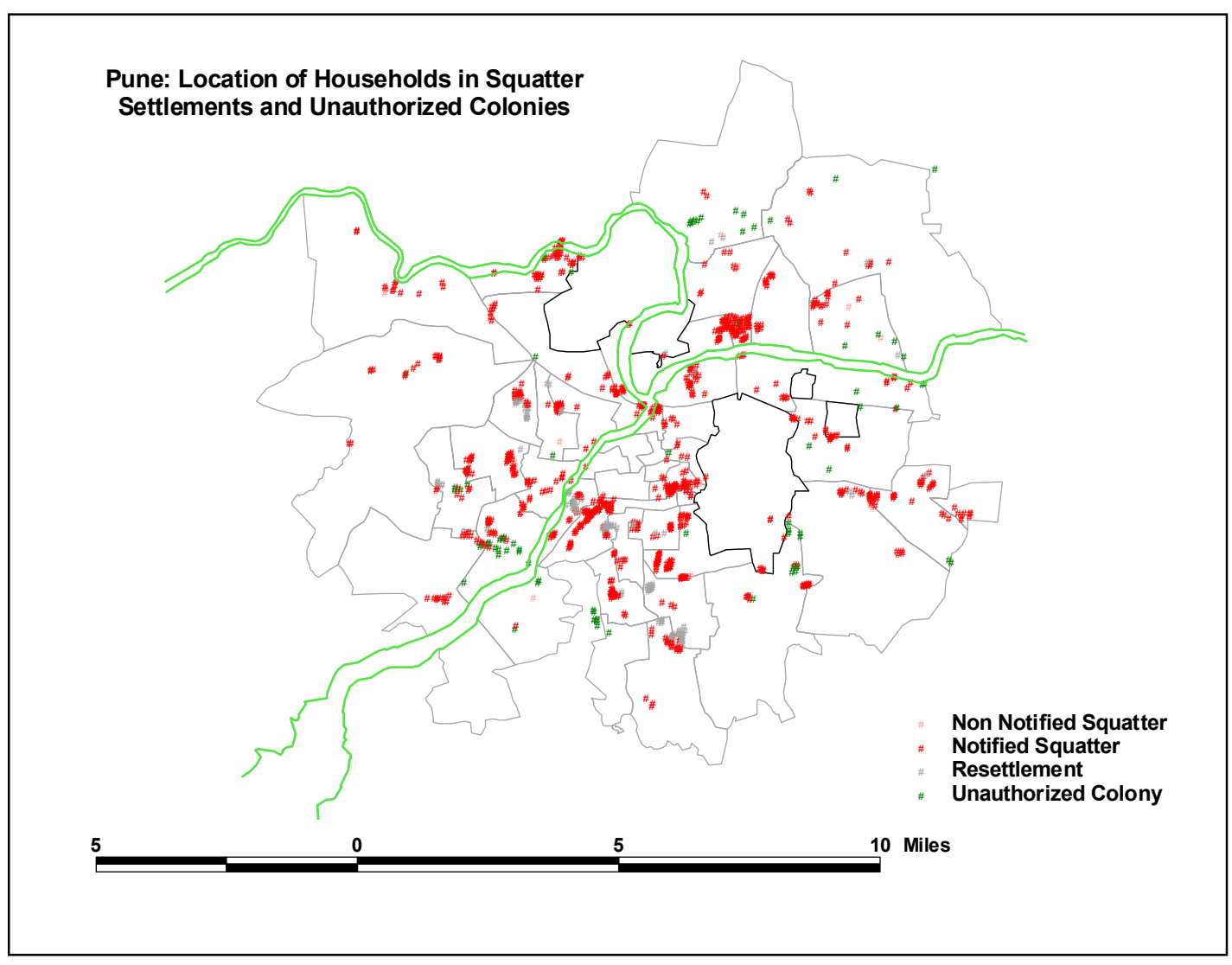


Figure 2: Travel to work

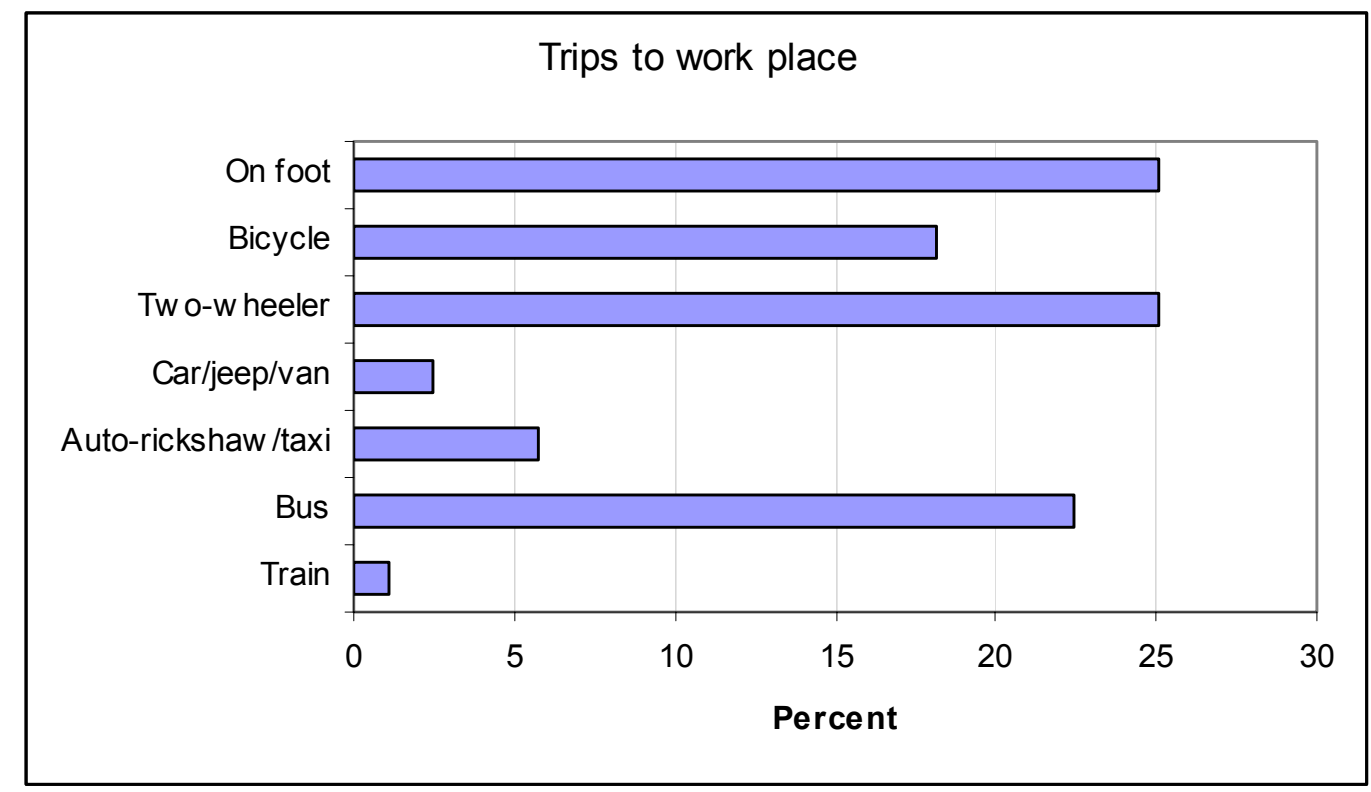

Source: Pune Household Survey, 2001, The World Bank; Travel Diary data 
Figure 3: Welfare change from alternative interventions

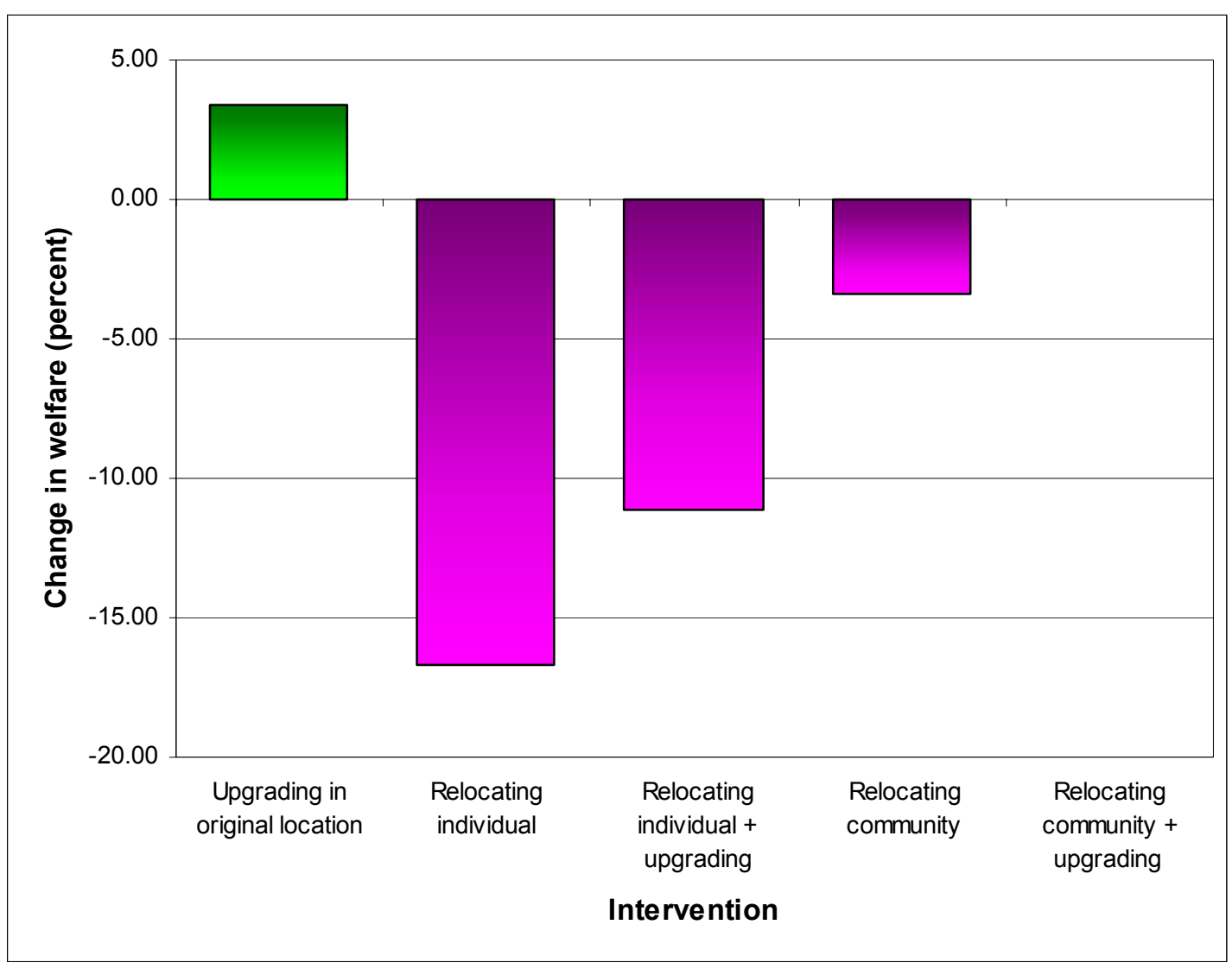

